\title{
PRAKSIS POLITIK NABI MUHAMMAD SAW (Sebuah Tinjaun Teori Politik Modern dan Ketatanegaraan)
}

\author{
FAJAR \\ Fakultas Syari'ah dan Hukum Islam IAIN Bone \\ Email: fajarphilosophy@gmail.com
}

\begin{abstract}
This paper examines the praxis (actions) of the Prophet Muhammad in the phase of Mekka and Madina with the viewpoint of modern political theory. The aim is to provide a theoretical and rational explanation that the actions of the Prophet can not only be seen from a religious viewpoint but can also be seen from a political perspective in measures of political and state theory. One of the Prophet's political actions in the Mecca phase was to build agreements with representatives from the city of Yastrib in the event of the first and second Bai'at Aqabah. The event in the size of political science can be called a social contract, namely building a social agreement to form a joint political entity. So that the event is considered as the first fundamental foundation of the building of the Islamic State. Politically, the Bai'at event can be read like a meeting of two interests in one historical momentum. First, the interests of Muhammad as a messenger of Allah to transmit Islamic teachings to the people of Yastrib. Second, the interests of the Yatsrib community for the presence of a leader who was able to mediate in the social conflict between them - a conflict between the Aus tribe and the never-ending Khazraj tribe. While in the Medina phase, the Prophet's political action was to build a written agreement as a common legal basis that became a guideline for the people of Medina in acting, both socially and politically. This political document is called Shahifah in the original text and later experts call it the Medina constitution, which is the basis for the formation of a state for the Muslim community in Madina.
\end{abstract}

Keyword: Muhammad;Political Praxis;Political Theory

\begin{abstract}
Abstrak
Tulisan ini mengkaji praksis (tindakan) politik Nabi Muhammad pada fase Mekkah dan Madinah dengan sudut pandang teori politik modern. Tujuannya untuk memberikan penjelasan teoritis dan rasional bahwa tindakan Nabi tidak hanya dapat dilihat dalam sudut pandang agama melainkan dapat juga dilihat dalam sudut pandang politik dalam ukuran-ukuran teori politik dan katatanegaraan. Salah satu tindakan politik Nabi pada fase Mekkah adalah
\end{abstract}


Jurnal Al-Adalah: Jurnal Hukum dan Politik Islam

Vol. 4, No. 1, Januari 2019:82-98

P-ISSN: 2406-8802

E-mail: aladalah@iain-bone.ac.id

http://jurnal.iain-bone.ac.id/index.php/aladalah

membangun kesepakatan-kesepakatan dengan beberapa perwakilan dari kota Yatsrib dalam peristiwa Bai'at Aqabah pertama dan kedua. Peristiwa tersebut dalam ukuran ilmu politik dapat disebut kontrak sosial, yaitu membangun kesepakatan sosial untuk membentuk satu kesatuan politik bersama. Sehingga peristiwa itu dianggap sebagai dasar fundamen pertama bangunan Negara islam. Secara politis, peristiwa bai'at itu dapat dibaca sebagai pertemuan dua kepentingan dalam satu momentum sejarah. Pertama, kepentingan Muhammad sebagai utusan Allah untuk mentransmisikan ajaran islam pada masyarakat Yatsrib. Kedua, kepentingan masyarakat Yatsrib atas hadirnya satu sosok pemimpin yang mampu menengahi konflik sosial di antara mereka - konflik antara suku Aus dan suku Khazraj yang tidak berkesudahan. Sedang pada fase madinah, tindakan politik Nabi adalah membangun perjanjian tertulis sebagai landasan hukum bersama yang menjadi pedoman bagi masyarakat Madinah dalam bertindak, baik secara sosial maupun secara politik. Dokumen politik itulah yang disebut Shahifah dalam teks aslinya dan belakangan para ahli menyebutnya sebagai konstitusi madinah, yaitu landasan bagi terbentuknya suatu negara bagi komunitas muslim di Madinah.

Kata kunci: Muhammad; Praksis Politik;Teori Politik

\section{A. Pendahuluan}

Sejarah kenabian Muhammad umumnya dibagi ke dalam dua fase. Yakni fase Mekkah dan fase Madinah. Artinya, aktifitas Dakwah Nabi pertama-tama dimulai di Mekkah dan kemudian berpuncak di kota Madinah. Dalam dua fase sejarah itulah kajian ini akan memotret aktifitas Muhammad dalam sudut pandang teori politik modern.

Berbeda dengan masyarakat Mekkah yang sebagian besar memusuhi Muhammad, bahkan menolak kebenaran risalah islam, masyarakat Madinah justru bersikap sebaliknya, yakni terbuka menerima seruan dakwah Nabi Muhammad SAW Keterbukaan masyarakat Madinah terhadap Dakwah Muhammad ditandai dengan kesediaan mereka menerima Islam sebagai agama mereka, serta bersaksi bahwa tidak ada Tuhan selain Allah dan Muhammad utusan Allah. Hal tersebut terekam dalam sebuah memori sejarah yang umum disebut dengan peristiwa Bai'at Aqoba I dan Bai'at Aqobah II. Ada dua hal penting Dalam peristiwa Bai'at tersebut: pertama, persaksian akan ke-Esaan Allah SWT serta membenarkan ajaran dan kerasulan Muhammad; kedua, kesediaan mereka memberikan loyalitas kepada Muhammad baik sebagai utusan Allah maupun sebagai pemimpin. Demikian peristiwa Bai'at itu bisa dilihat dalam dua sudut pandang, yaitu, sudut pandang teologis dan sudut pandang politik. Pengakuan mereka akan ke Esaan Allah dan kerasulan Muhammad adalah perisiwa teologi, sedang kesedian mereka 
untuk loyal kepada Muhammad sebagai pemimpin adalah peristiwa politik. Oleh karena itu, kajian ini akan membedakan antara Muhammad sebagai Nabi (utusan) Allah dan Muhammad sebagai manusia (politik). Pembedaan ini penting, agar tidak ada beban teologis dalam menganalisis dan mengindentifikasi aktivitas Muhammad dari sudut pandang politik dan sejarah, baik pada fase mekkah maupun pada fase Madinah.

Muhammad sebagai Nabi, tentu dengan segenap keyakinan - kita semua sependapat bahwa Muhammad adalah Nabi sekaligus Rasul Allah yang dipilih atau diangkat langsung oleh Allah SWT untuk menyampaikan risalah agama kepada umat manusia. Sedangkan Muhammad sebagai manusia politik (zoon politicon) dalam kajian ini kita asumsikan sebagai manusia yang tidak lepas dari berbagai kepentingan yang ingin diwujudkan, baik keinginan yang berorientasi pada kemuliaan akhirat maupun pada orientasi yang bersifat sosial kemanusiaan yang profan.

Tulisan ini akan menggunakan berbagai macam pendekatan dan teori untuk mengidentifikasi aktivitas-aktivitas Nabi Muhammad yang beraspek politik. Tujuannya untuk menggambarkan bahwa tindakan Muhammad tidak hanya dapat dilihat dalam kategori-kategori tindakan yang beraspek teologis murni, melainkan juga dapat dilihat dalam kategori-kategori tindakan yang beraspek politik. Dalam hal ini penulis akan menjelaskan tindakan Nabi Muhammad dengan menggunakan pendekatan-pendekatan teori politik modern untuk menghadirkan suatu penjelasan yang tidak hanya berbeda, namun juga menghadirkan suatu gagasan baru untuk pengembangan dalam bidang pemikiran politik islam.

\section{B. Pembahasan}

Praksis politik yang dimaksud dalam kajian ini adalah tindakan politik Muhammad baik pada fase Mekkah maupun pada fase Madinah, seperti: Bai'at Aqabah, peristiwa hijrah, dan langkah politik Muhammad sebagai pemimpin politik di Madinah.

\section{Bai'at Aqabah; Praksis Politik Nabi Muhammad Pra Hijrah}

Perubahan besar yang dialami Nabi bersama pengikutnya dari kelompok powerless (tanpa kekuasaan) menjadi suatu komunitas yang memiliki kekuatan sosial politik ditandai dengan beberapa peristiwa penting. ${ }^{1}$ Pada fase Mekkah, Muhammad, menjalankan aktifitas politik dengan dua metode gerakan, yaitu gerakan intelektual disamping gerakan sosial. Gerakan intelektual yang dimaksud disini adalah upaya Nabi Muhammad untuk melakukan transformasi pemikiran masyarakat dari paradigma politeisme ke paradigma monoteisme, sehingga berdampak pada perubahan keyakinan dan orientasi moral masyarakat. Yakni perubahan dari moralitas jahiliyah ke moralitas islami, disamping transformasi

\footnotetext{
${ }^{1}$ Suyuthi Pulungan, 1999, Fiqh Siyasah: Ajaran, Sejarah dan Pemikiran, Cet. 4, Jakarta: PT. RajaGrafindo Persada, hal. 78-79.
} 
pemahaman dari kepercayaan pada banyak tuhan ke kepercayaan akan keMahaesaan Tuhan, dengan cara mengedukasi masyarakat melalui dakwah Islam.

Hal ini sangat penting, karena perubahan sikap dan kepribadian setiap individu akan terjadi jika ada perubahan pada pemahaman (pemikiran). Nabi Muhammad cukup memahami hal itu, sehingga pendekatan kultural (pendidikan) menjadi satu-satunya langkah awal yang relevan untuk mewujudkan perubahan pada level pemikiran. Sekiranya kita semua memahami bahwa, unsur budaya yang paling fundamental adalah "pemikiran". Perubahan pada level pemikiran berkonsekuensi pada perubahan di level sikap dan kepribadian individu. Tentu perubahan yang dimaksud Muhammad adalah berubahnya sikap dan pribadi individu-masyarakat menjadi pribadi islami yang bersandar pada moralitas dan kesadaran akan kebenaran ajaran Islam. Dapat dikatakan, Muhammad pada fase Mekkah fokus membumikan nilai-nilai Islam, sehingga Islam tidak hanya menjadi ajaran moral yang abstrak dan melangit melainkan ia mengindividu atau memanusia. Dalam artian, Islam berwujud menjadi keyakinan serta sikap dan kepribadian masyarakat. Inilah yang disebut proses pelembagaan nilai, yakni proses internalisasi nilai Islam sehingga berbuah sikap dan tindakan dalam arus sosial, tepatnya menjadi moralitas kolektif masyarakat. Singkatnya, Islam dalam hal ini memanusia atau mengindividu pada fase Mekkah.

Selain menggunakan pendekatan kutural (gerakan intelektual), Rasulullah juga menggunakan metode gerakan sosial, gerakan sosial yang dimaksud disini adalah kemampuan Muhammad dalam mendayagunakan segala sumber daya dan peluang politik yang ada untuk meraih legitimasi politik dari masyarakat yang menjadi objek dakwahnya. Gerakan sosial umumnya menjadi jalan bagi mereka yang bergerak diluar kekuasaan politik, kekuasaan politik yang dimaksud adalah kewenangan otoritatif yang berlandaskan pada hak moral yang diakui oleh masyarakat untuk menentukan arah kebijakan negara secara absah.

Sebagaimana pemahaman umum, pada periode Mekkah pengikut Muhammad relatif kecil belum menjadi suatu komunitas yang mempunyai daerah kekuasaan yang berdaulat. Mereka merupakan golongan minoritas yang lemah dan tertindas, sehingga tidak mampu tampil menjadi kelompok sosial penekan terhadap kelompok sosial mayoritas kota itu yang berada di bawah kekuasaan aristokrat Quraisy yang masyarakatnya homogen. Dakwah Rasulullah SAW ditolak oleh sebagian besar masyarakat Mekkah, mereka bahkan melacarkan permusuhan kepada Rasulullah dan para pengikutnya di Mekkah. Lain halnya dengan masyarakat Yatsrib yang justru terbuka menerima dakwah Rasulullah SAW.

Pada tahun 621 dan $622 \mathrm{M}$, Nabi berturut-turut memperoleh dukungan moral dan dukungan politik dari sekolompok orang Arab (suku Aus dan suku Khazraj) kota Yatsrib yang menyatakan diri masuk Islam. Peristiwa ini 
mempunyai keistimewaan tidak seperti orang Arab Mekkah masuk Islam. Karena disamping mereka menerima Islam sebagai agama mereka, mereka juga membai'at Nabi. ${ }^{2}$ Dalam bai'at di tahun $621 \mathrm{M}$, dikenal dengan Bai'at Aqabah pertama, mereka berikrar bahwa mereka tidak akan menyembah selain Allah, akan meninggalkan segala perbuatan jahat dan akan menaati Rasulullah dalam segala hal yang benar. Sedangkan pada bai'at tahun $622 \mathrm{M}$, dikenal dengan Bai'at Aqabah kedua, mereka berjanji akan melindungi Nabi sebagaimana melindungi keluarga mereka dan akan mentaati beliau sebagai pemimpin mereka. ${ }^{3}$ Ada dua hal penting dalam peristiwa bai'at tersebut: pertama, persaksian akan keesaan Allah SWT serta membenarkan ajaran dan kerasulan Muhammad; kedua, kesediaan mereka memberikan loyalitas kepada Muhammad Baik sebagai utusan Allah maupun sebagai pemimpin.

Demikian peristiwa bai'at itu dapat dilihat dalam dua sudut pandang, yaitu: sudut pandang teologis dan sudut pandang politik. Pengakuan mereka akan ke-Esaan Allah dan kerasulan Muhammad adalah perisiwa yang bersifat teologis, sedangkan kesedian mereka untuk loyal kepada Muhammad sebagai pemimpin adalah peristiwa politik, tepatnya apa yang dalam ilmu politik disebut sebagai kontrak sosial, yaitu penyerahan hak-hak kekuasaan kepada Nabi untuk mengatur kehidupan sosial dan politik mereka.

Fakta itu menunjukan bahwa antara Muhammad dan penduduk Yatsrib itu telah terjadi "fakta persekutuan". Karena kedua pihak mencapai kesepakatan supaya saling menjaga dan melindungi keselamatan bersama. Dalam bai'at kedua tergambar pula adanya penyerahan hak kekuasaan diri dari peserta bai'at kepada Nabi yang mereka akui sebagai pemimpin mereka. Dalam ilmu politik disebut dengan kontrak sosial. Peristiwa tersebut mengantarkan umat Islam dari kelompok kecil manusia yang lemah menjadi satu komunitas politik yang kuat di Madinah di bawah komando Nabi Muhammad SAW. Sehingga dikatakan, dua bai'at itu adalah dasar fundamen yang mengantarkan umat Islam menjadi komunitas masyarakat negara. Kedua peristiwa itu dianggap sebagai pondasi pertama bangunan Negara Islam.

Berdasarkan dua bai'at itu, Nabi Muhammad menganjurkan pengikutpengikutnya untuk hijrah ke Yatsrib pada akhir tahun itu juga, dan beberapa bulan kemudian Nabi sendiri hijrah bergabung dengan mereka. ${ }^{4}$ Secara politis, peristiwa bai'at itu dapat dibaca sebagai pertemuan dua kepentingan dalam satu momentum sejarah. Pertama, kepentingan Muhammad sebagai utusan Allah untuk mentransmisikan ajaran Islam pada masyarakat Yatsrib. Kedua, kepentingan

\footnotetext{
${ }^{2}$ Suyuthi Pulungan, Ibid., hal. 79.

${ }^{3}$ Ibid., hal. 79.

${ }^{4}$ Munawir Sjadzali, 2003, Islam dan Tata Negara: Ajaran, Sejarah dan Pemikiran, Ed. 5, Jakarta: UI-Press, hal. 9.
} 
masyarakat Yastrib atas hadirnya satu sosok pemimpin yang mampu menengahi konflik sosial di antara mereka - yakni konflik antara suku Aus dan suku Khazraj yang tidak berkesudahan. Konflik demi konflik yang yang terjadi antara suku Aus dan Khazraj itulah yang melahirkan kesadaran kedua suku itu akan perdamaian. Sehingga mendorong mereka melakukan bai'at atau apa yang disebut dalam ilmu politik dengan kontrak sosial. Yaitu kesepakatan di antara anggota masyarakat untuk membentuk satu kesatuan politik bersama, disamping sumpah setia untuk memberikan loyalitas dan ketaatan penuh kepada personal (Muhammad) atau lembaga yang kelak melahirkan otoritas untuk mengatur kehidupan sosial-politik mereka.

Demikian dalam sudut pandang gerakan sosial, peristiwa Bai'at Aqabah tersebut, membuka peluang politik bagi Muhammad untuk mendapatkan ketaatan dari penduduk Yatsrib, baik ketaatan yang bersifat agamis maupun ketaatan yang bersifat politis. Ketaatan dari sisi agama adalah pengakuan penduduk Yatsrib atas kerasulan Muhammad, sedangkan ketaatan dari sisi politik adalah ketaatan penduduk Yastrib kepada Muhammad sebagai pemimpin masyarakat. Itu artinya, kepemimpinan Muhammad sebagai pemimpin masyarakat secara fakta terwujud melalui kontrak sosial. Dengan kata lain, diperoleh secara de facto melalui kesepakatan sosial di antara masyarakat Yatsrib. Akan tetapi, juga tidak bisa dinafikkan bahwa kepemimpinan Muhammad dijalankan berdasarkan moralitas Islam yang universal, yaitu kepemimpinan yang diorientasikan untuk memaksimalkan kebaikan dan keadilan di tengah-tengah masyarakat dan sekaligus menumpas segala kezhaliman dan ketidakadilan di masyarakat.

Sehingga Islam tidak hanya menjadi simbol yang diyakini melainkan ia menjadi praksis atau langkah nyata untuk membumikan keadilan bagi mereka yang mengalami penindasan di bawah sistem sosial yang menindas sebagaimana terjadi di kota Mekkah. Kahadiran Muhammad di tengah-tengah masyarakat Yatsrib tidak hanya mendatangkan maslahat bagi umat Islam, tapi juga mendatangkan maslahat bagi penganut agama lain diluar Islam, termasuk kelompok lain yang masih hidup dengan agama lama mereka, yakni para penyembah berhala dan kaum Yahudi. Mereka diberikan kebebasan menjalankan agama sesuai dengan keyakinan agama masing-masing.

Sampai pada titik ini, tepatlah jika dikatakan bahwa Muhammad dalam menjalankan misi kenabiannya menyampaikan risalah Islam tidak hanya menggunakan pendekatan agama atau spiritual, melainkan juga menggunakan pendekatan-pendekatan yang bersifat politik. Yakni mendayagunakan segala sumber daya dan kesempatan politik yang ada untuk memudahkan misinya dalam menyebarkan agama Islam. Singkatnya, Muhammad, dalam membumika Islam selain menggunakan cara-cara agama, ia juga menggunakan tindakan-tindakan atau langkah-langkah politik, yaitu mengorganisasi masyarakat ke dalam suatu 
tatanan sosial-politik dengan membentuk sistem hukum sebagai pedoman bersama dalam bertindak dan berinteraksi, serta membentuk sistem kekuasaan sebagai satu orientasi loyalitas bersama yang sah dan berlegitimasi, yakni sah secara hukum juga diakui oleh masyarakat, yakni masyarakat Yatstrib.

\section{Hijrah sebagai Praksis Politik Nabi Muhammad}

Peristiwa hijrah terjadi pada tahun ke-13 kenabian. Dimana peristiwa hijrah itu bukan semata-mata atas kehendak Muhammad, catatan sejarah menyatakan peristiwa hijrah itu terjadi karena ada undangan langsung dari para pemuka atau tokoh-tokoh masyarakat dari Yastrib sesaat setelah mereka melakukan kontrak sosial (Bai'at) di bukit Aqobah.

Sabagaimana diutarakan dalam bahasan sebelumnya, peristiwa bai'at itu dapat dibaca sebagai pertemuan dua kepentingan dalam satu momentum sejarah. Pertama, kepentingan Muhammad sebagai utusan Allah untuk mentransmisikan ajaran Islam. Kedua, kepentingan masyarakat Yatsrib atas hadirnya satu sosok pemimpin yang mampu menengahi konflik sosial di antara mereka, yakni konflik antara suku Aus dan suku Khazraj yang tidak berkesudahan. Sehingga mereka menganggap bahwa Muhammadlah sosok yang tepat menjadi mediator damai sekaligus sebagai pemimpin mereka. Mahammad satu-satunya harapan mereka untuk menyelesaikan konflik sosial yang berkepanjangan di antara mereka. Sebab, apabila salah-satu dari dua suku itu yang memegang kendali kekuasaan, tentu suku yang lain akan menentang dan menolak untuk memberikan layolitas, sehingga kodisi demikian akan selalu berujung pada konflik dan semakin mempertajam pertentangan di antara mereka. Dengan demikian, dalam kondisi yang tidak menentu, dimana konflik sewaktu-waktu dapat terjadi di antara mereka ,maka salah satu jalan keluarnya adalah mengundang Muhammad hijrah ke kota Yatsrib, dengan harapan hadirnya Muhammad mampu menciptakan stabilitas sosial dan mampu membangun tatanan sosial-politik yang tertib, damai, dan penuh dengan persaudaraan di antara mereka.

Peristiwa hijrah itu tidak semata-mata adalah peristiwa dalam rangkah menegakkan agama, melainkan peristiwa itu juga bisa dibaca sebagai peristiwa politik. Dimana suatu gerakan sosial yang diupayakan di Mekkah, berbuah negara di Madinah. Singkatnya, Islam pada fase Madinah tidak hanya memanusia melainkan telah berkembang menjadi masyarakat politik atau negara. Islam menjadi identitas bersama sebagai satu kesatuan yang utuh dan sebagai satu komunitas politik. Tepatnya Islam bermetamorfosis menjadi masyarakat politik di Madinah. Dimana di dalamnya ada sistem kekuasaan, juga sistem hukum yang menjadi pegangan setiap warga negara dalam bertindak dan berinteraksi dalam kehidupan sosial dan politik.

Apa yang kemudian dilakukan Rasulullah SAW sesaat setelah tiba di Madinah, relatif mirip dengan semua yang mungkin dilakukan para pemimpin 
politik yang baru mendirikan negara: Pertama, membangun infrastruktur negara dengan masjid sebagai simbol dan perangkat utamanya; kedua, menciptakan kohesi sosial melalui proses persaudaraan antarkomunitas darah yang berbeda tapi menyatu sebagai komunitas agama, antara sebagian komunitas Quraisy dan Yatsrib menjadi komunitas Muhajirin dan Anshar; ketiga, membuat nota kesepakatan untuk hidup bersama dengan komunitas lain yang berbeda, sebagai sebuah masyarakat pluralistik yang mendiami wilayah yang sama, melalui Piagam Madinah; keempat, membentuk angkatan perang untuk menghadapi ancaman invasi dari kafir Qurasy Mekkah.

Dapat dikatakan, masyarakat Madinah di bawah pimpinan Muhammad, selain dihubungkan dengan ikatan agama, mereka juga diikat oleh ikatan kebangsaan, yakni hidup damai secara bersama-sama dalam satu wilayah territorial yang mandiri. Tepatnya diikat oleh adanya kesamaan kewarganegaraan karena mereka hidup bersama-sama sabagai satu komunitas warga negara dalam situasi dan kondisi masyarakat yang heterogen (plural) yang kemudian mereka dipersatukan dengan lahirnya satu perjanjian bersama yang disebut dengan Piagam Madinah (konstitusi madinah).

\section{Praksis Politik Nabi Muhammad SAW di Madinah: Negara Madinah dan Piagam Madinah}

Untuk menentukan apakah piagam madinah layak disebut sebagai konstitusi atau hukum dasar yang melandasi tegaknya sebuah negara, terlebih dahulu kita mesti menjelaskan masyarakat Madinah sebagai masyarakat politik yang hidup bernegara dengan kriteria yang didasarkan pada teori politik dan ketatanegaraan modern.

Negara secara hakikat merupakan konstruksi yang diciptakan oleh umat manusia (human creation) tentang pola hubungan antar manusia dalam kehidupan bermasyarakat yang diorganisasikan sedemikian rupa untuk maksud memenuhi kepentingan dan mencapai tujuan bersama. Menurut H.J.W. Hetherington sebagaimana dikutip C.F. Strong dalam bukunya, Konstituai-konstitusi Politik Modern, Negara adalah institusi atau seperagkat institusi yang menyatukan penduduknya dalam suatu wilayah teritorial yang ditandai secara jelas di bawah otoritas tunggal yang menjamin tercapainya tujuan dasar dan kondisi kehidupan bersama. $^{5}$

${ }^{5}$ C.F. Strong, 2015, Konstitusi-Konstitusi Politik Modern: Studi Perbandingan Tentang Sejarah dan Bentuk, Bandung: Nusa Media, hal. 6. 
Menurut Appadorai dalam Jimly Asshiddiqie, apabila kumpulan orang bermasyarakat itu diorganisasikan untuk mencapai tujuan sebagai satu unit pemerintahan tertentu, maka perkumpulan itu dapat dikatakan diorganisasikan secara politik, dan disebut body politic atau Negara (state) sebagai a society politically organized. ${ }^{6}$

Dari dua pandangan tersebut, suatu negara apa pun bentuk serta sistem pemerintahannya dan siapa pun pemimpinnya, apakah dipimpin oleh seorang Nabi atau para agamawan bukanlah lembaga yang sakral. Karena ia lahir dari kreasi manusia sebagai makhluk rasional yang membudaya, yakni lahir dari masyarakat yang pada hakikatnya membutuhkan kehidupan sosial yang terorganisir, tertib, taat, dan damai.

Kehadiran suatu negara dalam kehidupan masyarakat adalah suatu keniscayaan yang sifatnya rasional. Dikatakan bersifat rasional, karena ia lahir dari kesadaran manusia yang secara fitrah selalu hidup berkelompok, dimana kelompok manusia ini menghendaki terwujudnya kepentingan bersama dan kebaikan bersama sebagai satu komunitas yang utuh. Jadi kehadirannya negara dalam kehidupan manusia adalah sebuah keniscayaan, baik dari kelompok manusia yang beragama maupun kelompok manusia yang tidak beragama sekalipun. Artinya, negara bukanlah lembaga yang lahir dari kesadaran agama melainkan lahir dari kesadaran rasional kelompok manusia. Karenanya, negara bukanlah lembaga agama yang sakral. Namun, tentu saja sistem pengaturan negara bisa saja didasarkan pada moralitas-etik agama yang terobjektifikasi dengan bahasa publik. Yaitu bahasa atau istilah yang mencerminkan kehendak bersama yang melampaui bahasa normatif agama, namun secara substansial mewakili kehendak seluruh kelompok sosial dan secara prinsipil tetap sejalan dengan semangat moralitas-etik agama, misalnya: keadilan, demokrasi (syura'), kebaikan bersama, dan kesetaraan (egalitarianisme). Karena itu, Negara Madinah, jika dipandang sebagai Negara, walaupun dipimpin langsung oleh Muhammad sebagai Rasul Allah, tetap harus dilihat sebagai lembaga yang sifatnya profan (duniawi). Artinya, lembaga negara tersebut adalah alat (wasilah) untuk menegakkan keadilan dan kebaikan bersama yang bersandar pada nilai-nilai kemanusiaan yang sejalan dengan nilai-nilai fundamen agama yang universal. Dalam hal ini Muhammad menjadikan lembaga negara tersebut sebagai alat untuk memudahkan misinya dalam mentransmisikan ajaran Islam.

Ini terlihat setelah Muhammad hijrah ke Madinah, posisi Nabi dan umat Islam mengalami perubahan besar. Di Madinah, tulis Harun Nasution dalam Suyuthi Pulungan, mereka mempunyai posisi yang baik dan segera menjadi suatu komunitas umat yang kuat dan dapat berdiri sendiri. Nabi sendiri menjadi

6 Jimly Asshiddiqie, 2006, Pengantar Ilmu Hukum Tata Negara, Cet. I, Jakarta: Sekretariat Jendral dan Kepaniteraan MK RI, hal. 13. 
pemimpin masyarakat yang baru dibentuk itu, dan akhirnya menjadi suatu negara. Suatu Negara yang wilayah kekuasaannya di akhir zaman Nabi meliputi seluruh Semenanjung Arabia. ${ }^{7}$ Fazlur Rahman, tokoh Neomodernisme Islam, juga membenarkan bahwa masyarakat Madinah yang diorganisir Nabi itu merupakan suatu Negara dan pemerintahan yang membawa kepada terbentuknya suatu komunitas masyarakat muslim. ${ }^{8}$

Pertanyaan kita, apa kriteria dan unsur-unsur untuk memenuhi tegaknya suatu negara? Pada dasarnya, negara memiliki unsur-unsur yang melekat di dalamnya. Sejumlah pemikir menyebutkan negara terdiri dari tiga unsur penting, yaitu wilayah, penduduk, dan pemerintahan yang berdaulat ketiga unsur ini disepakati sebagai sesuatu yang harus ada di dalam negara. Jika salah satunya tidak ada, maka tidak bisa disebut negara. ${ }^{9}$ Konvensi Montevideo pada tahun 1993 menyebutkan unsur-unsur berdirinya suatu negara antara lain harus ada wilayah yang dinyatakan sebagai milik bangsa dan batas-batasnya ditentukan melalui perjanjian internasional, selajutnya harus ada rakyat yang mendiami wilayah tersebut dan dapat terdiri atas berbagai golong sosial, serta harus ada pemerintahan yang berhak mengatur dan berwenang merumuskan serta melaksanakan peraturan perundang-undangan yang mengikat warganya. ${ }^{10}$

Jika diukur dengan kriteria tersebut, berdirinya negara pada masa Nabi Muhammad SAW di Madinah adalah sautu hal yang jelas ketiga unsur tersebut terpenuhi. Ada rakyat, yaitu golongan besar dan kecil. Ada wilayah tertentu, yakni Madinah. Ada pemegang kekuasaan pemerintahan yang berdaulat, yaitu Muhammad yang dipatuhi oleh umumnya warga Madinah dan tidak ada penguasa lain yang membawahinya. Di dalam naskah Konstitusi Madinah, tiga unsur negara itu telah disebutkan secara jelas: unsur rakyat adalah semua golongan yang disebutkan dalam piagam, yang umum disebut ahl hazihi al-shahifah (pasal 37, 39, 42, 46); wilayah ialah Yatsrib (pasal 39) atau madinah (pasal 47); pemerintah ialah Muhammad (mukaddimah dan pasal 23, 36, 42). ${ }^{11}$

Negara terdiri atas unsur manusia, tanah, dan pemerintahan atau kekuatan politik. Dalam konteks Siyasah Syar'iyah sebagian ulama, seperti Muhammad Abdullah al-Arabi merasa bahwa tiga unsur tersebut tidak cukup untuk membangun negara, karena ketiganya baru merupakan unsur materi dan perlu

${ }^{7}$ J. Suyuthi Pulungan, 1996, Prinsip-prinsip Pemerintahan dalam Piagam Madinah ditinjau dari pandangan al-Quran, Cet. II, Jakarta: PT RajaGrafindo Persada, hal. 1-2.

${ }^{8}$ Ibid., hal. 2.

9 Ahmad Sukarja, 2012, Hukum Tata Negara dan hukum Adiministrasi Negara dalam Perspekftif Fiqih Siyasah, Cet. 1, Jakarta: Sinar Grafika, hal. 51.

${ }_{10}$ Ahmad Sukarja, Ibid., h. 51-52. Lihat juga Huala Adolf, 2003, Aspek-aspek Negara dalam Hukum Internasional, Jakarta: Raja Grafindo, hal.3.

${ }^{11}$ Ahmad Sukarja, Ibid., hal. 52. 
ditambahkan unsur lain yang bersifat ruhi, yaitu prinsip Islam. Prinsip inilah yang membedakan negara "komunitas Islam" dengan selainnya. ${ }^{12}$

Demikian dalam catatan sejarah disebutkan, penduduk kota Yatsrib tidak seperti kota Mekkah yang berpenduduk homogen, penduduk Yatsrib plural dari sisi agama, juga plural dari sisi etnisitas dan bangsa. Di dalamnya ada dua suku besar yang selalu bersaing yaitu suku Aus dan suku Khazraj, kedua suku besar itu selalu diwarnai dengan konflik sosial maupun konflik kepentingan akibat masih menguatnya ego sukuisme diantara mereka. Demikian hal itu terjadi karena tidak ada satu sistem hukum yang menjadi pedoman bersama dalam beperilaku dan bertindak, pun juga tidak ada sistem kekuasan yang absah (legitimate power) yang mampu mempersatukan masyarakat dengan otoritas dan kekuasaan yang sah dan diakui luas oleh masyarakat.

Selain dua suku tersebut di atas, di Madinah juga ada bangsa Yahudi yang mengusai bidang pertanian dan perdagangan. Kemudian dari sisi agama atau keyakinan, juga bersifat plural karena ada agama Yahud dan nada pula Zoroaster (para penyembah api), dan termasuk pula agama Islam sebagai agama baru bagi penduduk Yatsrib. Walaupun agama ini masih baru bagi penduduk Yatsrib tapi sangat diminati karena nilai-nilainya sejalan dengan nilai kemanusiaan universal, serta nila-nilainya yang berorientasi pada egalitarianisme (kesetaraan), keadilan, dan demokratisasi.

Dari uraian tersebut, terjawablah bahwa: Pertama, dari sisi wilayah tentu saja masyarakat Islam di bawah pimpinan Muhammad mendiami wilayah Yatsrib yang kemudian berubah nama menjadi Madinah ketika Muhammad hijrah dan tiba di kota itu. Di kota Madinah tidak hanya ada muslim, tetapi juga kaum Yahudi, dan sebagian kelompok masyarakat Yatsrib yang masih menyembah berhala. Jadi unsur pertama sudah terpenuhi, yaitu: wilayah.

Kedua, masyarakat - sudah dijelaskan sebelumnya, wilayah Madinah didiami oleh beragam suku, bangsa, dan etnisitas, termasuk beragam keyakinan atau agama. Dari sisi entinisitas ada suku Aus dan Khazraj sebagai penduduk asli (pribumi), di dalamnya juga ada suku Quraisy yaitu kelompok migran (muhajirin) yang berasal dari Mekkah. Kemudian dari sisi agama penduduk Madinah menganut beragam agama, yaitu: Yahudi, Zoroaster, Nasrani, dan Islam. Ketiga, pemerintahan yang berdaulat - masyarakat Madinah, tidak hanya merupakan kumpulan manusia, melainkan mereka adalah komunitas masyarakat politik yang dipimpin langsung oleh Muhammad seorang Rasul Allah.

Kendati demikian, Negara Madinah tentu saja tidak bisa dipersamakan dengan kualitas negara modern yang pengaturannya sudah lebih kompleks. Struktur masyarakat Madinah masih terbilang sederhana karena itu negaranya pun juga diatur secara sederhana dengan satu produk hukum bersama, yaitu Konstitusi

\footnotetext{
${ }^{12}$ Muhammad Elvandi, 2011, Inilah Politikku, Solo: Era Adicitra Intermedia, hal. 27.
} 
Madinah. Inilah yang menjadi pedoman bersama bagi warganegara Madinah dalam berelasi dan berinteraksi di dalam kehidupan sosial dan politik.

Rasulullah Muhammad SAW memperoleh dukungan kuat dari warga Yatsrib. Dukungan tersebut tidak peroleh secara tiba-tiba, melainkan tumbuh dengan perlahan yang diawali dengan kesepakatan-kesepakatan mereka semasa Muhammad masih berada di Mekkah. Namun dukungan tersebut tidak membuat posisi Muhammad benar-benar kuat, sebab penduduk Madinah menurut pembagian genealogi maupun etnis dan keyakinan, terbagi ke dalam beberapa kelompok sosial yang berbeda dalam cara berfikir dan kepentingan. Untuk itu, beliau membuat perjanjian tertulis yang dapat diterima oleh semua kelompok sosial yang bercorak mejemuk itu. ${ }^{13}$

Telah disebutkan bahwa beberapa saat setelah tinggal di Madinah, Rasulullah berupaya menciptakan kebersamaan dan keharmonisan dalam kemajemukan masyarakat dengan membuat pernjanjian tertulis yang tertuang dalam Piagam Madinah. Piagam ini dikategorikan sebagai undang-undang suatu negara yang baru muncul, yang di dalamnya mengatur kekuasaan politik, hak-hak manusia, pengelolaan urusan masyarakat. Ia merupakan peraturan asasi mengenai sistem politik dan sosial bagi komunitas Islam dan mengatur hubungan dengan komuitas lainnya. Dapat diketahui bahwa perjanjian itu tidak saja menghadirkan sebuah masyarakat, namun juga merupakan dokumen yang mendasari terbentuknya sebuah negara. ${ }^{14}$ Tepatnya dokumen tersebut adalah sebuah konstitusi atau landasan bagi terbentuknya suatu negara.

Tewujudnya Piagam Madinah merupakan bukti sifat kenegarawanan Muhammad. Beliau tidak hanya mementingkan umat Islam, tetapi juga mengakomodasi kepentingan orang-orang Yahudi dan mempersatukan kedua umat serumpun ini di bawah kepemimpinannya. Bagi umat Islam, Nabi Muhammad berhasil menciptakan persatuan dan kesatuan serta persaudaraan di antara kaum Muhajirin dan Anshar, juga suku-suku dikalangan Anshar sendiri. Dikalangan Anshar, Nabi diakui telah merekat kembali hubungan antarsuku yang sebelumnya selalu bermusuhan. ${ }^{15}$ Dalam perjanjian tertulis itu, Nabi diakui sebagai pemimpin tertinggi dan sebagai hakam bagi penandatanganan Piagam serta siapa saja yang bergabung dengan mereka. ${ }^{16}$ Menurut Ahmad Syafii Maarif dalam Suyuthi, apa yang dituangkan dalam Piagam Madinah, adalah penjabaran prinsip-prinsip kemasyarakatan yang yang diajarkan Al-Quran, sekalipun wahyu belum lagi rampung diturunkan, atau Piagam Madinah merupakan aktualisasi dari

\footnotetext{
${ }^{13}$ J. Suyuthi Pulungan, Op. Cit., hal. 87.

${ }^{14}$ Ridwan HR, 2007, Fiqih Politik: Gagasan, Harapan, dan Kenyataan, Yogyakarta: FH UII Press, hal. 134-135.

${ }^{15}$ Muhammad Iqbal, 2007, Fiqh Siyasah: Kontekstualisasi Doktrin Politik Islam, Jakarta: Gaya Media Pratama. hal 69.

${ }^{16}$ Ibid., hal. 70 .
} 
ajaran Al-Quran dalam kehidupan sosial politik dan sosial budaya. Akan tetapi Suyuthi Pulungan menyatakan, kesimpulan ini jelas kurang sesuai dengan kenyataan sejarah. Sebab, biasanya suatu penjabaran dan aktualisasi dilakukan setelah ada sesuatu yang mendahului yang memerlukan penjelasan. Artinya, ada ayat atau wahyu yang sudah turun, kemudian dijelaskan atau diaktulisasikan oleh Nabi sesuai dengan tugasnya menurut satu ayat bahwa Allah menurunkan AlQuran kepada Muhammad SAW, sebagai Rasul-Nya, untuk menjelaskan kepada manusia tentang apa-apa yang diturunkan kepada mereka supaya mereka berpikir. ${ }^{17}$ Karena itu, menurut Suyuthi Pulungan, rumusan ketetapan piagam dapat dikatakan merupakan produk ketetapan atau refleksi dari pemikiran dari Nabi Muhammad SAW dan bersifat temporer, "bukan penjabaran dan aktualisasi dari prinsip-prinsip kemasyarakatan yang diajarkan Al-Quran”. Sebab, disamping ayat-ayat tentang kemasyarakatan pada waktu itu belum turun sempurna, juga tidak ditemui keterangan Nabi dan sahabat bahwa beliau membuat piagam itu berdasarkan petunjuk wahyu. Sementara posisi beliau dikalangan umat pada masa hidupnya, mejadi referensi dalam mengatur segala urusan yang bersifat umum. Kenyataan ini menjadi bukti bahwa ketetapan Nabi merumuskan peraturan dan undang-undang kemasyarakatan dalam Piagam itu mendahului ayat-ayat tentang kemasyarakatan yang belum turun sempurna, dan ini merupakan langkah politik atau siyasat Rasul, untuk mewujudkan kemaslahatan bagi masyarakat luas. ${ }^{18}$

Langkah politik tersebut diputuskan Muhammad secara mandiri tanpa ada tuntunan dari wahyu Allah. Akan tetapi tentu Muhammad sangat menyadari bahwa inisiatif tersebut tidak bertentangan dengan wahyu Allah. Langkah Muhammad tersebut, jika ditinjau dengan pendekatan politik hukum, produk hukum yang dilahirkan di dalam Negara Madinah adalah produk politik. Tepatnya, hasil kesepakatan bersama antar warga negara yang digali dari nilainilai dan norma-norma sosial atau tradisi masyarakat setempat tanpa mengabaikan nilai-nilai Islam. Sehingga dengannya produk hukum tersebut ditaati dan dipedomani oleh masyarakat Madinah, baik dalam berinteraksi secara sosial maupun secara politik. Dikatakan sebagai produk politik karena tidak mungkin sebuah aturan hukum dapat ditaati dan dipedomani masyarakat tanpa disepakati terlebih dahulu oleh semua elemen masyarakat yang berkepentingan terhadap aturan tersebut. Dalam artian, Konstitusi Madinah adalah dokumen politik tertulis yang lahir dari kesepakatan masyarakat. Dalam hal ini Piagam Madinah berfungsi sebagai nuktah-nuktah kesepakatan antara berbagai golongan untuk mewujudkan masyarakat politik.

Maka poin penting yang ingin disampaikan pada kajian ini, adalah: Pertama, Muhammad dalam mengatur masyarakatnya bukan dengan syariat Islam

\footnotetext{
${ }^{17}$ J. Suyuthi Pulungan, Op. Cit., hal. 3.

${ }^{18}$ J. Suyuthi Pulungan, Ibid., hal. 4
} 
secara formalistik (bukan dengan norma agama), melainkan dengan nilai-nalai dan norma-norma masyarakat setempat yang sejalan dengan semangat syariat Islam secara substansial; Kedua, kekuasaan Muhammad tidak hanya diarahkan untuk melindungi kepentingan masyarakat muslim, melainkan ditujukan juga untuk melindungi segenap kepentingan seluruh warga masyarakat Madinah baik yang beragama Islam maupun yang beragama Yahudi, termasuk para pemyembah berhala yang masih bertahan dengan keyakinan mereka.

Demikian Nurcholish Majid menyebutkan dalam M. Syafii Anwar, Konstitusi Madinah merupakan rumusan tentang prinsip-prinsip kesepakatan antara msyarakat Yatsrib (Madinah) di bawah pimpinan Nabi Muhammad dengan berbagai kelompok bukan muslim kota itu untuk membangun suatu masyarakat politik (polity) bersama. Dalam konstitusi itu untuk pertama kalinya dirumuskan ide-ide yang dalam ilmu politik modern sakarang ini dikenal; misalnya kebebasan beragama, hak setiap kelompok untuk mengatur kehidupan sesuai dengan keyakinannya, kemerdekaan hubungan ekonomi dan politik antar golongan, kewajiban untuk berpartisipasi dalam usaha pertahanan bersama, dan sebagainya. ${ }^{19}$ Oleh karena itu, masyarakat muslim dan non muslim pimpinan Muhammad menerima Piagam Madinah atas dua pertimbangan. Pertama, nilainilainya dibenarkan ajaran Islam. Kedua, berfungsi sebagai dokumen politik yang berisi kesepakatan antar berbagai golongan yang ada dalam kota Madinah untuk mewujudkan kesatuan politik bersama.

Secara politis Konstitusi Madinah dapat dikatakan sebagai wujud kebijakan politik Nabi dalam bidang hukum, tepatnya merupakan pilihan hukum yang akan diberlakukan untuk mencapai tujuan negara. Jadi Konstitusi Madinah dapat disebut wujud pernyataan kehendak penguasa negara dan masyarakat atas produk hukum yang diberlakukan di dalam suatu negara untuk mewujudkan kehendak umum atau kebaikan bersama. Dengan kata lain Konstitusi Madinah merupakan kristalisasi dan legalisasi atas berbagai kehendak dan kepentingan politik yang ada di dalam masyarakat Madinah yang sejatinya plural secara agama, etnisitas, dan suku bangsa. Sebagaimana dipahami secara umum bahwa istilah konstitusi berasal dari bahasa Perancis, "constituer" yang berarti membentuk. Pemaknaan istilah konstitusi yang dimaksudkan ialah pembentukan suatu negara atau menyusun dan menyatakan suatu negara". ${ }^{20}$ Menurut C.F. Strong, konstitusi dapat pula dikatakan sebagai kumpulan prinsip-prinsip yang mengatur kekuasaan pemerintahan, hak-hak pihak yang diperintah (rakyat) dan hubungan di antara keduanya. ${ }^{21}$ Lanjut C.F. Strong, tujuan konstitusi adalah

${ }^{19}$ M. Syafi'i Anwar, 1995, Pemikiran dan Aksi Islam Indonesia, Jakarta: Paramadina, hal. 195.

${ }^{20}$ Muhammad Alim, 2010, Asas-asas Negara Hukum Modern dalam Islam, Yogyakarta: LKiS, hal. 61.

${ }^{21}$ C.F. Strong, Op. Cit., hal. 15 
membatasi membatasi tindakan sewenang-wenang pemerintah, menjamin hak-hak dan kewajiban rakyat yang diperintah, dan menetapkan kekuasaan yang berdaulat. $^{22}$

Pertanyaannya, apa indikator untuk mengatakan Piagam Madinah sebagai sebuah konstitusi? Sovernin Lohman dalam Ahmad Sukarja menjelaskan bahwa dalam konstitusi harus memuat unsur-unsur sebagai berikut:

1) Konstitusi dipandang sebagai perwujudan perjanjian masyarakat (kotrak sosial), artinya bahwa konstitusi merupakan konklusi dari kesepakatan masyarakat untuk membina negara dan pemerintahan yang akan mengatur mereka;

2) Konstitusi sebagai piagam yang menjamin hak azasi manusia dan warga negara sekaligus penentuan batas-batas hak dan kewajiban warganegara dan alat-alat pemerintahannya;

3) Konstitusi sebagai forma regimenis, yaitu kerangka dari bangunan pemerintahan. $^{23}$

Mengacu pada tiga unsur muatan konstitusi sebagaimana tersebut di atas, dapat dikatakan bahwa Piagam Madinah layak disebut sebagai konstitusi. Pertama, Piagam Madinah lahir dari kesepakatan antar berbagai golongan untuk membentuk satu kesatuan politik di wilayah kota Madinah. Jika Piagam Madinah meruapakan hasil kesepakatan, itu artinya Piagam Madinah adalah wujud dari kontrak sosial dalam rangka membentuk masyarakat politik atau negara. Kedua, Piagam Madinah secara tegas mengatur tentang hak-hak dasar warga negara, misalnya kebebasan menjalankan ibadah sesuai dengan kayakinan agama masingmasing warga negara. Ketiga, Piagam Madinah mengatur secara tegas bahwa kekuasaan tertinggi ada di tangan Muhammad sebagai pemimpin negara. Oleh karena itu, Piagam Madinah sebagai konstitusi merupakan produk politik yang lahir dari kontrak sosial atau merupakan hasil inisiatif Nabi sebagai bentuk kebijakan Nabi sebagai penguasa politik yang berwenang untuk membentuk suatu produk hukum dengan tujuan untuk memenuhi kepastian hukum dan tertib sosial dalam kehidupan bernegara. Muhammad, sangat menyadari bahwa kepastian hukum menjadi dasar untuk mewujudkan ketertiban sosial karena adanya suatu norma yang menjadi pedoman bersama dalam berperilaku dan bertindak. Itu artinya, suatu produk hukum dihadirkan untuk mewujudkan ketaatan, juga untuk memberikan sanksi bagi yang melanggar demi tercapainya kebaikan bersama seluruh warga negara.

\title{
C. Penutup
}

\author{
${ }^{22}$ C.F. Strong, Ibid., hal. 16 \\ ${ }^{23}$ Ahmad Sukardja, Op. Cit., hal. 91
}


Tindakan Nabi Muhammad yang berimplikasi secara politik tergambar pada dua fase sejarah, yaitu dimulai dari perjalanan sejarah kenabian Muhammad pada fase Mekkah yang di dalamnya terjadi peristiwa Bai'at Aqabah sebagai dasar fundamen bangunan negara bagi komunitas Islam pertama, serta fase Madinah dimana Muhammad mempersatukan masyarakat Madinah ke dalam satu kesatuan politik bersama melalui perjanjian tertulis yang disebut dengan Konstitusi Madinah. Secara politis peristiwa Bai'at Aqobah merupakan langkah politik Nabi Muhammad yang dimotivasi oleh pertemuan dua kepentingan dalam satu momentum sejarah., yaitu kepentingan Muhammad untuk mentransmisikan ajaran Islam bagi penduduk Yatsrib dan kepentingan masyarakat Yatsrib atas hadirnya satu sosok pemimpin yang dapat menghimpun mereka ke dalam tatanan sosial yang tertib, damai dan berkeadilan. Dua kepentingan tersebut diwujudkan melalui perjanjian tertulis (Piagam Madinah) sebagai wujud kebijakan politik Nabi dalam bidang hukum, tepatnya merupakan pilihan hukum yang diberlakukan untuk mencapai tujuan negara. Jadi Piagam Madinah dapat disebut wujud pernyataan kehendak antara Muhammad sebagai penguasa dan masyarakat Madinah atas produk hukum yang diberlakukan di dalam suatu negara demi mewujudkan kebaikan bersama. Dengan kata lain Piagam Madinah merupakan kristalisasi dan legalisasi berbagai kepentingan politik yang ada dalam masyarakat Madinah yang sejatinya plural secara agama, etnisitas, dan suku bangsa untuk mewujudkan kepastian hukum dan terttib sosial.

\section{DAFTAR PUSTAKA}

Asshiddiqie, Jimly, 2016, Pengantar Ilmu Hukum Tata Negara, Cet. I Jakarta: Sekretariat Jendral dan Kepaniteraan MK RI.

Pulungan, J. Suyuthi, 1996, Prinsip-prinsip Pemerintahan dalam Piagam Madinah ditinjau dari pandangan al-Quran, Cet. II Jakarta: PT RajaGrafindo Persada. , 1999, Fiqh Siyasah: Ajaran, Sejarah dan Pemikiran, Cet. 4, Jakarta, PT. RajaGrafindo Persada.

Alim, Muhammad, 2010, Asas-asas Negara Hukum Modern dalam Islam, Yogyakarta: LKiS.

Sjadzali, Munawir, 2003, Islam dan Tata Negara: Ajaran, Sejarah dan Pemikiran, Ed. 5, Jakarta, UI-Press.

Sukarja, Ahmad, 2012, Hukum Tata Negara dan hukum Adiministrasi Negara dalam Perspekftif Fiqih Siyasah, Cet. 1, Jakarta, Sinar Grafika.

Adolf, Huala, 2003, Aspek-aspek Negara dalam Hukum Internasional, Jakarta, Raja Grafindo.

Elvandi, Muhammad, 2011, Inilah Politikku, Solo, Era Adicitra Intermedia. Iqbal, Muhammad, 2007, Fiqh Siyasah: Kontekstualisasi Doktrin Politik Islam, Jakarta, Gaya Media Pratama. 
C.F. Strong, 2015, Konstitusi-Konstitusi Politik Modern: Studi Perbandingan tentang Sejarah dan Bantuk, Terj. Derta Sri Widowatie, Cet. 10, Bandung, Nusa Media.

Ridwan, 2007, Fiqh Politik: Gagasan, Harapan, dan Kenyataan, Yogyakarta, FH UUI Press. 